\title{
THE MAIN DIRECTIONS OF ENSURING FOOD SECURITY IN THE DEVELOPMENT OF FAT AND OIL INDUSTRY
}

\author{
Yuldashev Abdukhakim Abdukarimovych, \\ $\mathrm{PhD}$ student, Tashkent State University of Economics, Tashkent, \\ The Republic of Uzbekistan \\ abduxakim@bk.ru
}

\section{Original Scientific Paper doi:10.5937/jouproman6-18271}

\begin{abstract}
This article is devoted to the priorities of the development of the oil-and-gas industry of the Republic of Uzbekistan and its role in the economy of the country, sustainable development of the production of raw materials and oil-and-fat products, and measures to ensure food security in the oil and fat industry. Providing the population with quality foodstuffs, especially with ecologically clean vegetable oils, which are rich in various vitamins and human organisms, as well as achieving the "Fat-free independence" in the republic and increasing the productivity of surplus goods, by introducing free currency earnings orientation to socio-economic life of the country. If the amount of soybean production increases in the country, we will be stepping forward to provide food security through poultry and beef and meat products not only from oilseed oils and shrimp. The author provides for food security in the republic, filling the domestic market with high quality fat-andoil products, modernization of oil and fat industry, launching new capacities, increasing the quality and productivity of oil-bearing plants, is one of the pressing issues, with the reduction of imports and increasing export volumes.
\end{abstract}

Key words: food security, oil-bearing plants, oil, agricultural production, oil and fat products.

\section{Introduction}

Food industry plays a crucial role today in meeting the needs of the population of our country for food security and high quality food. Therefore, sustainable development of domestic food and raw materials production is one of the main tasks for the market to supply safe and high quality food products in a set of consumer standards. After the independence of the Republic of Uzbekistan, the high-tech food industry is becoming one of the leading sectors of the economy. Particular attention is paid to ensuring food security, saturation of the domestic market with high quality food products, modernization of production, launch of new capacities, and manufacturing of import substituting products. Measures to stimulate and support the modernization and diversification of production provide for the growth of food production.

In order to ensure socio-economic development of the country, the Decree of the President of the Republic of Uzbekistan Mirziyoyev on February 7, 2017, "On Strategy for Action in the Five Priorities of Development of the Republic of Uzbekistan in 2017-2021", special attention to food security in the priorities of economic development and liberalization. deepening of structural changes and gradual development of agricultural production, food security of the country further strengthening of production, expansion of production of ecologically clean products, considerable increase of export potential of the agrarian sector. 
Nevertheless, the level of provision of the population with quality oil and fat products is low. In particular, the foreign trade turnover of the Republic of Uzbekistan in 2017 is 26,983,283.9 thousand. 2149 791,4 thousand US dollars. The U.S. dollar has a share of food products. Fat-oil products made up 115377.9 thousand. Table 1 illustrates the US dollar.

Uzbekistan is a country with many years of experience and high scientific potential in agriculture. In our country, a lot of work has been done to ensure food security during the years of independence. In particular, as a result of the measures taken to improve the crop production and improve the logistics system, last year, about 3 million tonnes of cotton, 8.3 million tonnes of wheat, 21 million tonnes of fruits and vegetables, including 3 million tonnes of potatoes, 3 million tons of fruit, 2 million tons of melons, more than 1.7 million tons of grapes, 3 million tons of fruits and berries were harvested and harvested .There are great opportunities for oil and fat production in the Republic of Uzbekistan. The fat-and-oil industry is well-developed. At present, there are 23 large oil and gas companies in the country, and also 42 small oil-producing shops. Despite the potential for such a large capacity, we can not achieve a significant growth in oil and fat production in the country. The main reason for this is that the raw material base for oil and fat production is falling. Secondly, the composition of the raw material base for oil and fat is also changing. And that's a lot of new problems. In particular, it is necessary to change the techniques and technologies of the existing oil and fat production enterprises. This, in turn, requires large investments in the oil and fat industry. It is very difficult to find and invest in these investments.
Oil and fat enterprises in the country have the capacity to process 2700 thousand tons of oil and fat vegetable per year. In 2016, 105,720 tonnes of oil and vegetable crops were harvested in the country (excluding cotton seeds). This sector, which has a positive impact on the improvement and deepening of integration processes in the country's agro-industrial complex, is also important in addressing the issues of improving the quality and expanding the range of products, the full and partial use of raw materials, and the needs and employment of the population.

The country's vegetable oils account for $27 \%$ of the population's demand for vegetable oils. In order to ensure food security, it is necessary to increase the production of vegetable oil and to grow oilseeds.

According to the Cabinet of Ministers of the Republic of Uzbekistan dated February 2, 2017, the Program on Increasing the Production of Non-Traditional Oil Seeds was approved in order to ensure food security in our country. In order to ensure the implementation of the program, the oil and fat industry of the "Uzbekoziqovkatkholding" holding company plans to plant 3900 hectares, including 2300 hectares of sage and 1600 hectares of sunflower unstable oilseeds. This, in turn, allows increasing oil and fatand-oil companies' capacities to increase the production capacity of the population and increase the supply of oil and fat products, as well as create new jobs.

At the same time, the President of the Republic of Uzbekistan Sh.Mirziyoev on the 7th of February, 2017-2021, in the third priority direction of the "Action Strategy" in the five priority areas of the Republic of Uzbekistan, Section 3.3 "... 
Reduce the area of cotton and cereals, the implementation of systematic measures to plant potatoes, vegetables, fodder and lubricant crops on the ground ", the Presidential Decree of March 14, 2017," Planting soybean crops in the country for 2017-2021 a resolution No. PQ-2832 of the Ministry of Agriculture and Water Resources, the Uzpakhtasanoateksport holding company and the Uzpaxtayog joint stock company aimed at providing the population with cheap and high quality vegetable oils, adapted to various soil and climatic conditions seeds and hybrids of the shade resistant, ripe, fertile, resistant to disease and pest, as well as attracting foreign partners with advanced experience in the production of high-fat soybean crops the implementation of narrow tasks.

The Program "Measures to Extend and Increase the Processing of Oil Fields in the Republic of Karakalpakstan and the Regions", annually approved by the Cabinet of Ministers of the Republic of Uzbekistan, meanwhile, the State Program has unconditional economic significance in order to implement these priorities in social life it means. Because any program, plan, or action taken in social life, or the ongoing reforms, will have economic significance along with political, social, and spiritual content. There is something in the ground of such normative-legal documents. This is accompanied by providing the population with high-quality food products, especially vegetable oils which are rich in various vitamins, which are environmentally friendly and useful for human organisms, as well as achieving the "Fat-free independence" in the republic and increasing the productivity of surplus goods, to direct the country's socioeconomic life by introducing foreign exchange gains. If we increase the amount of soybean production in our country, we will be stepping forward not only to provide fat-andoil products, but also shade and poultry, as well as food and beef cattle and meat products.

\section{Literature review}

No scientific research on econometric modeling of economic efficiency of fat-andoil-producing enterprises of the Republic of Uzbekistan has been conducted. Foreign scientists M.O. Sinegovskiy, Yu.V. Melnikova, D.G. Pereverzev, Z.P. Medelyaeva, I.I. Bosaya, T.V. Savchenko, A.V. Ulezko, N. Kravchenko, V.I. Nechaev and A.V. Ostretsova and others have carried out scientific researches and wrote literature on this topic. However, according to the findings of their scientific works, there are not enough recommendations for practical use in the sector of oil and fat industry development of our country.

\section{Analisys and results}

Food industry plays a crucial role today in meeting the needs of the population of our country for food security and high quality food. Therefore, sustainable development of domestic food and raw materials production is one of the main tasks for the market to supply safe and high quality food products in a set of consumer standards. After the independence of the Republic of Uzbekistan, the high-tech food industry is becoming one of the leading sectors of the economy. Particular attention is paid to ensuring food security, saturation of the domestic market with high quality food products, modernization of production, launch of new capacities, and manufacturing of import substituting products. Measures to stimulate and support the modernization and diversification of production provide for the growth of food production. 
In order to ensure socio-economic development of the country, the Decree of the President of the Republic of Uzbekistan Mirziyoyev on February 7, 2017 "On Strategy for the Strategy of Development of the Republic of Uzbekistan in 2017-2021", special emphasis on food security in the priorities of economic development and liberalization deepening structural changes and gradual development of agricultural production, country food threatening further strengthening of the scorecard, expansion of production of ecologically clean products, considerable increase of export potential of the agrarian sector. [4] However, the level of access to good quality oil and fat products remains low. In particular, the foreign trade turnover of the Republic of Uzbekistan in 2017 is 26,983,283.9 thousand. 2149 791,4 thousand US dollars. The U.S. dollar has a share of food products. Fat-oil products made up 115377.9 thousand. Table 1 illustrates the US dollar.

(Table-1).

Table-1

\section{Share of oil and fat products in foreign trade turnover}

\begin{tabular}{|l|c|c|c|c|c|c|}
\hline \multirow{2}{*}{} & \multicolumn{2}{|c|}{$2015 \mathrm{y}$} & \multicolumn{2}{c|}{$2016 \mathrm{y}$} & \multicolumn{2}{c|}{$2017 \mathrm{y}}$. \\
\cline { 2 - 7 } & thousand USD & $\begin{array}{c}\text { share in, } \\
\%\end{array}$ & thousand USD & $\begin{array}{c}\text { share in, } \\
\%\end{array}$ & thousand USD & $\begin{array}{c}\text { share in, } \\
\%\end{array}$ \\
\hline $\begin{array}{l}\text { Foreign trade } \\
\text { turnover }\end{array}$ & 24924266,4 & 100,0 & 24232215,2 & 100,0 & 26983283,9 & 100,0 \\
\hline Foodstuffs & 2901654,0 & 11,6 & 2134178,4 & 8,8 & 2149791,4 & 8,0 \\
\hline $\begin{array}{l}\text { Oil and fat } \\
\text { products }\end{array}$ & 176105,9 & 6,1 & 177214,2 & 8,3 & 115377,9 & 5,4 \\
\hline
\end{tabular}

Source: State Statistics Committee data.

Table 1 shows that in 2017, the share of foodstuffs in Uzbekistan in the foreign trade turnover was $8 \%$, of which oil and fat products $-5.4 \%$.

Uzbekistan is a country with many years of experience and high scientific potential in agriculture. In our country, a lot of work has been done to ensure food security during the years of independence. In particular, as a result of the measures taken to improve the crop production and improve the logistics system, last year, about 3 million tonnes of cotton, 8.3 million tonnes of wheat, 21 million tonnes of fruits and vegetables, including 3 million tonnes of potatoes, , 3 million tons of fruit, 2 million tons of melons and gourds, more than 1.7 million tons of grapes, 3 million tons of fruits and berries were harvested and harvested [2].

It is seen in Figure 1 below that in 2017, the share of imported foodstuffs in the country is about 8 percent. 


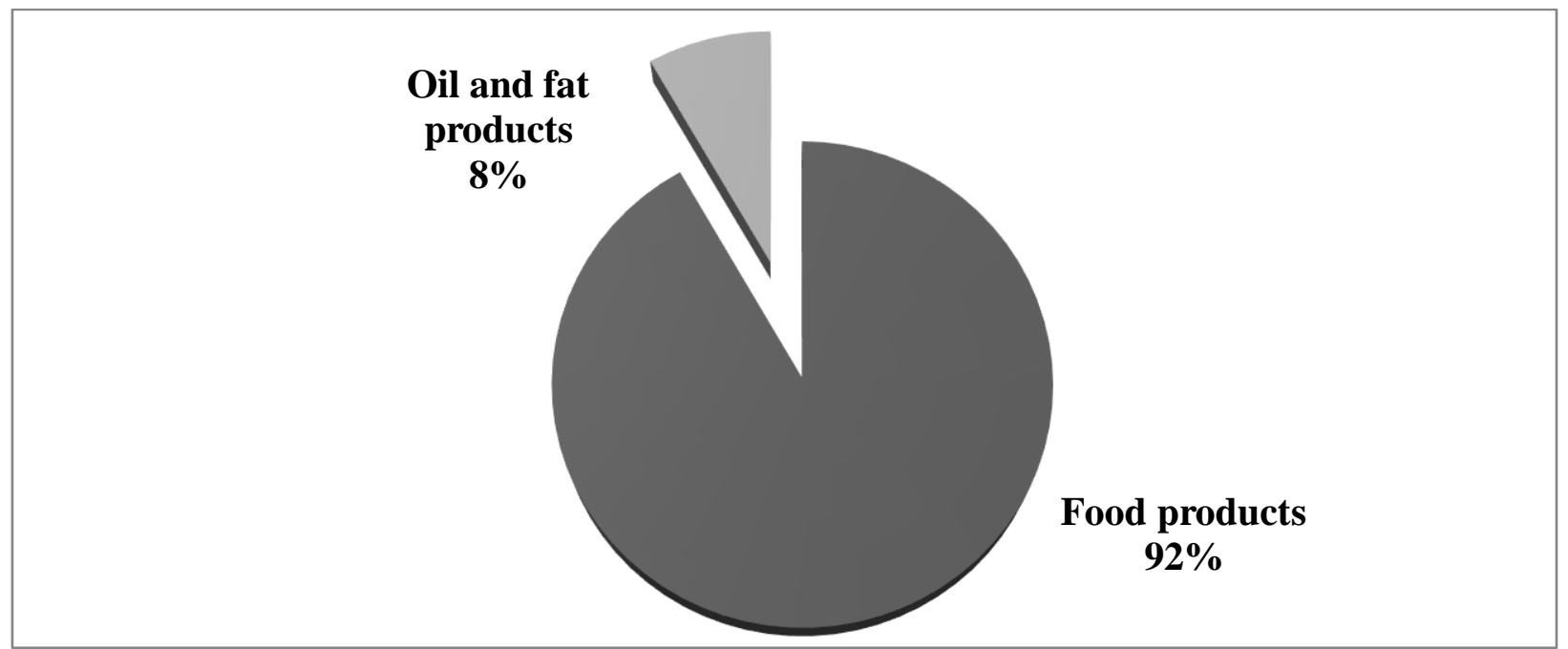

Fig. 1. Share of oil and fat products imported into the country in food products in 2017. Source: State Statistics Committee data.

There are great opportunities for oil and fat production in the Republic of Uzbekistan. The fat-and-oil industry is welldeveloped. At present, there are 23 large oil and gas companies in the country, and also 42 small oil-producing shops. Despite the potential for such a large capacity, we can not achieve a significant growth in oil and fat production in the country. The main reason for this is that the raw material base for oil and fat production is falling. Secondly, the composition of the raw material base for oil and fat is also changing. And that's a lot of new problems. In particular, it is necessary to change the techniques and technologies of the existing oil and fat production enterprises. This, in turn, requires large investments in the oil and fat industry. It is very difficult to find and invest in these investments.

Oilseed crops in tonnage throughout the country (tons)

\begin{tabular}{|l|c|c|c|c|}
\hline & $\mathbf{2 0 1 3} \mathbf{y}$ & $\mathbf{2 0 1 4} \mathbf{~ y}$ & $\mathbf{2 0 1 5} \mathbf{y}$ & $\mathbf{2 0 1 6}$ y. \\
\hline Sunflower for don & 39386 & 46488 & 50132 & 53839 \\
\hline Soybean & 439 & 395 & 1480 & 232 \\
\hline Kunjut & 4258 & 5155 & 6099 & 7935 \\
\hline Sneeze & 25858 & 21397 & 28880 & 31184 \\
\hline Peanut & 6399 & 6380 & 7170 & 9342 \\
\hline Other oilseed crops & 2218 & 2040 & 3508 & 3188 \\
\hline Total & 78558 & 81855 & 97269 & 105720 \\
\hline
\end{tabular}

Source: State Statistics Committee data.

Oil and fat enterprises in the country have the capacity to process 2700 thousand tons of oil and fat vegetable per year. In 2016, 105,720 tonnes of oil and vegetable crops were harvested in the country (excluding cotton seeds). This sector, which has a positive impact on the

Table-2 
Information on oil and fat products produced in the country (tons)

\begin{tabular}{|l|c|c|c|}
\hline & 2015 йил & 2016 йил & 2017 йил \\
\hline Soybean oil & 782,0 & 364,3 & 497,5 \\
\hline Sunflower oil & 22245,7 & 19659,0 & 3886,4 \\
\hline Cotton oil & 194965,2 & 203799,3 & 202372,5 \\
\hline Canola oil & 30,9 & $\mathrm{x}$ & $\mathrm{X}$ \\
\hline $\begin{array}{l}\text { Other types of vegetable } \\
\text { oils }\end{array}$ & 2870,9 & 3542,6 & 1117,6 \\
\hline Total & 220894,7 & 227365,2 & 207874 \\
\hline
\end{tabular}

Source: State Statistics Committee data.

In 2015, Uzbekistan produced $220,984,7$ tons of oil, 22,7365.2 tonnes in 2016 and 207874 tonnes of fat-and-oil products in Table 2. As can be seen from the table, the production of lubricating oil for 2017 is $3,886.4$ tonnes, which is $19,659.0$ tonnes in 2016 and 22,245.7 tonnes in 2015 . In 2017, 207874 thousand tons of vegetable oil was produced. If the population of the republic $(20,7874$ thousand tons) is vegetable oils $(32,120.5$ thousand), then we can see that 6.5 liters of herbal oil per person. However, according to the State Statistics Committee, in 2017 we can say that each population consumes $24.0 \mathrm{~kg}$ of vegetable oil per capita. Thus, the country's vegetable oils make $27 \%$ of the population's demand for vegetable oils. In order to ensure food security, it is necessary to increase the production of vegetable oil and to grow oilseeds. According to the Cabinet of Ministers of the Republic of Uzbekistan dated February 2, 2017, the Program on Increasing the Production of Non-Traditional Oil Seeds was approved in order to ensure food security in our country. In order to ensure the implementation of the program, the oil and fat industry of the "Uzbekoziqovkatkholding" holding company plans to plant 3900 hectares, including 2300 hectares of sage and 1600 hectares of sunflower unstable oilseeds. This, in turn, allows increasing oil and fat-and-oil companies' capacities to increase the production capacity of the population and increase the supply of oil and fat products, as well as create new jobs. At the same time, the President of the Republic of Uzbekistan Sh.Mirziyoev on the 7th of February, 2017-2021, in the third priority direction of the "Action Strategy" in the five priority areas of the Republic of Uzbekistan, Section 3.3 "... Reduce the area of cotton and cereals, [1], the Presidential Decree of March 14, 2017 "On planting soybean crops in the country for 2017-2021 and Resolution No. PQ-2832 "On measures to increase the production of soybean grains" was adopted by the Ministry of Agriculture and Water Management, Uzpakhtasanoateksport holding company and OJSC "Uzpakhtayog" to provide population with cheap and high quality vegetable oils, adapted to various soil and climatic conditions seeds and hybrids of soybeans, resistant to ripe, fertile, disease-resistant and pests, as well as involvement of foreign partners with advanced experience in the production of high-fat soybean crops [3].

On October 4, 2017, the 12th plenary session of the Senate of the Oliy Majlis of the Republic of Uzbekistan "In 2016, starting from the 2016 harvest, it is envisaged to reduce the cotton fields by 185,000 hectares or by $14.5 \%$. 
It is planned to plant cotton, vegetable, melon, fodder and leguminous crops and potatoes and build intensive gardens and vineyards. As a result, by 2020 the production of fruit and vegetable products, grapes and melons will be increased by at least 2.3 times. 3 years of agricultural exports will be increased by 3 times, "said Deputy Minister of Agriculture and Water Resources, Director General of the Agricultural Research and Production Center Shukhrat Teshaev to the senators [6]. In order to replenish cotton seeds
(185 thousand hectares) of cotton seeds and products for their processing, the Resolution of the President of the Republic of Uzbekistan "On measures to increase the production of soybean crops and increase the production of soybeans in 2017-2021" dated March 14, 2017201812 thousand hectares, of which 8 thousand hectares of main crops and 4 thousand hectares of crops were planted. By 2021 , the area of the soybean will be 40,000 hectares. [1]

\section{Information about shadow-producing countries}

\begin{tabular}{|l|c|c|c|c|c|c|}
\hline Countries & $\mathbf{2 0 1 1 y}$ & $\mathbf{2 0 1 2 y} \cdot$ & $\mathbf{2 0 1 3 y}$ & $\mathbf{2 0 1 4 y}$ & $\mathbf{2 0 1 5 y}$ & $\mathbf{2 0 1 6 y}$ \\
\hline United States & 83200 & 82100 & 89500 & 108000 & 108100 & 104000 \\
\hline Brazil & 71000 & 83500 & 89000 & 94500 & 86700 & 92000 \\
\hline Argentina & 48000 & 51500 & 54500 & 56000 & 49100 & 57000 \\
\hline Chinese & 13500 & 12600 & 12200 & 12400 & 11600 & 10300 \\
\hline Paraguay & 6400 & 7800 & 9000 & 8500 & 10800 & 9300 \\
\hline Indian & 11000 & 11500 & 11800 & 10500 & 8900 & 9200 \\
\hline Ukraine & 2300 & 2400 & 2800 & 3900 & 3900 & 4000 \\
\hline Russia & 1756 & 1806 & 1636 & 2539 & 2800 & 2800 \\
\hline Kazakhstan & 707 & 822 & 103 & 119 & 106 & 143 \\
\hline Uzbekistan & $\mathbf{0 , 9 7}$ & $\mathbf{1}$ & $\mathbf{0 , 4 3 9}$ & $\mathbf{0 , 3 9 5}$ & $\mathbf{1 , 4 8}$ & $\mathbf{0 , 2 3 2}$ \\
\hline Total & 237863,97 & 254029 & 270539,4 & 296458,395 & 282007,5 & 288743,23 \\
\hline
\end{tabular}

Source: State Statistics Committee data. [6]

The Program "Measures to Extend and Increase the Processing of Oil Fields in the Republic of Karakalpakstan and the Regions", annually approved by the Cabinet of Ministers of the Republic of Uzbekistan, meanwhile, the State Program has unconditional economic significance in order to implement these priorities in social life it means. Because any program, plan, or action taken in social life, or the ongoing reforms, will have economic significance along with political, social, and spiritual content. There is something in the ground of such normative-legal documents. This is accompanied by providing the population with high-quality food products, especially vegetable oils which are rich in various vitamins, which are environmentally friendly and useful for human organisms, as well as achieving the "Fat-free independence" in the republic and increasing the productivity of surplus goods, to direct the country's socioeconomic life by introducing foreign exchange gains. If we increase the amount of soybean production in our country, we will be stepping forward not only to provide fat-andoil products, but also shade and poultry, as well as food and beef cattle and meat products. 
(JPMNT) Journal of Process Management - New Technologies, International

Vol. 6, No 3, 2018.

\section{References}

1. The Decree of the President of the Republic of Uzbekistan dated February 7, 2017 "On Strategy for Action for the Further Development of the Republic of Uzbekistan"

No.

UP-4947.

2. The speech of the President of the Republic of Uzbekistan Sh.M.Mirziyoev at the Cabinet of Ministers meeting devoted to the results of socio-economic development of the country in 2016. 3. Resolution of the President of the Republic of
Uzbekistan from March 14, 2017 "About measures on increase of soybean crop cultivation and soybean production in the republic for 2017-2021" PQ-2832.

4. http://www.biznes-daily.uz/ru/birjaexpert/51984-oziq-ovqat-xavfsizligi--davlat-siyosatining-ustvoryunalishi-sifatida. 5.https://kun.uz/30457003?q=\%2F30457003. 6.http://www.oilworld.ru.

7.https://latifundist.com/spetsproekt/97-ukraina-nabobah. 